Sławomir Czapnik

Uniwersytet Opolski

\title{
Dialektyka polityki i kultury - na przykładzie Zygmunta Baumana
}

\section{Politics - Culture Dialectics: Case of Zygmunt Bauman}

\begin{abstract}
The aim of this article is stress that dialectic thinking is very fertile approach in a political theory research. Zygmunt Bauman's thought could be perceived as an example of usefulness of the dialectics in political research. Text contains three chapters. First outlines Bauman's dialectical dimension relationships between politics and culture. Second analyses politics as some specific cultural project. Last chapter is devoted to Polish edition reality show Supernanny. In summary author describes relevance of the Zygmunt Bauman's dialectic in a field of the political theory.
\end{abstract}

Keywords: dialectics, Zygmunt Bauman, liquid modernity, television

Dialektyka, zauważa Bertell Ollman (2003, s. 2), w takiej czy innej formie istniała na długo przed tym, zanim na Ziemi pojawił się człowiek. Działo się tak (i dzieje) dlatego, że życie zawsze zawiera w sobie istotne elementy zmiany $i$ interakcji. Nasze środowisko, jako całość, ostatecznie ogranicza i determinuje działania to, co istnieje dzisiaj, bierze się z tego, co było wczoraj, już uprzednio istniały bowiem możliwości, które ziściły się obecnie. To, co dzisiaj, zawiera w sobie ziarno tego, co zdarzy się jutro. Ludzie w zasadzie od zawsze próbowali pojąć rzeczywistość wokół nich, zrozumieć naturę systemu złożonego $\mathrm{z}$ wielu zintegrowanych elementów, łącząc to, co przeszłe, obecne i przyszłe. Tu należy szukać źródeł różnorodnej tradycji myślenia dialektycznego (Ollman, 2003, s. 2-3).

Jan Such wyróżnia trzy podstawowe wątki dialektycznych wizji świata:

Pierwszy wątek to genetyczno-rozwojowe ujmowanie eksplorowanej rzeczywistości, uznawanie historyczności za jeden z jej fundamentalnych wymiarów ontologicznych. Drugi to nacisk na konieczność uwzględniania w strukturze badanych przed- 
miotów momentów opozycyjnych (sprzeczności i przeciwieństw) oraz konieczność poszukiwania punktów jednoczących owe przeciwstawne momenty (jedność przeciwieństw). Trzeci wreszcie to uwzględnianie we wszystkich rozważaniach filozoficznych więzi podmiotowo-przedmiotowych jako niezbywalnych w strukturze bytu (Such, 1992, s. 4).

Tradycja myślenia dialektycznego bywała wykorzystywana $\mathrm{w}$ studiach politologicznych, włącznie z teorią polityki, lecz - zwłaszcza w krajach, w których dialektyka w wersji marksizmu-leninizmu była oficjalną doktryną ideologiczną (jak w Polskiej Rzeczypospolitej Ludowej) - uznano ją za narzędzie uwikłane politycznie, a zarazem nieprzydatne, przestarzałe. Moim zdaniem czas swoistej kwarantanny, nazwijmy ją postkomunistyczną, był wystarczająco długi, aby przypomnieć o płodności dialektyki w badaniach nad teorią polityki.

Pisanie o Zygmuncie Baumanie w ujęciu teoriopolitycznym jest o tyle zasadne, że być może Baumanowskie postrzeganie władzy jest jego największym osiągnięciem w analizie socjologicznej (Campain, 2008, s. 195). Przy czym kluczowe znaczenie ma krytyczne ujawnienie i przeanalizowanie mechanizmów panowania, wpływu i władzy grupy ludzi nad innymi; grupy, która zawsze stara się na różne sposoby uczynić swoją pozycję trwałą.

Należy zdawać sobie sprawę z faktu, że - jak pisze choćby Peter Nijhof (1998, s. 87) - styl pracy Baumana (włącznie, zauważmy, z jego rozważaniami o charakterze dialektycznym) może stanowić zagrożenie dla pewnych konwencji, których przestrzeganie jest powszechne wśród naukowców. Nijhof abstrahuje od podziałów między uczonymi, wkraczając na obszary kompetencji specjalistów w wielu dziedzinach. Bauman, nawet jeżeli nie pisze książek w narracji pierwszoosobowej, bierze pełną osobistą odpowiedzialność za swoje rozważania. Czytelnik obcuje z autorem uczciwym i niezwykle erudycyjnym, a nade wszystko zaangażowanym w rozmowę. Bauman, zaznacza Nijhof (1998, s. 87), łączy to, co sprawiedliwe, zabawne i prawdziwe, scalając zagadnienia o charakterze moralnym i naukowym, używając literackich środków do rozważań o charakterze analitycznym.

Artykuł składa się z trzech rozdziałów. Rozpoczyna się od szkicowego zarysowania Baumanowskiej dialektyki kultury i polityki. Druga część dotyczy nowoczesnej polityki jako kulturowej utopii. Trzeci rozdział skupia się na rozważaniach o emitowanej w latach 2006-2008 polskiej edycji programu Superniania.

Znane dialektyczne hasło feministek, głoszące, że to, co prywatne, jest publiczne, znacznie wcześniej niż one odkryli i wyciągnęli z niego praktyczne wnioski wolnorynkowi konserwatyści. „Silna rodzina to podstawa społeczeństwa” - ogłosił w roku 1984 prezydent Ronald Reagan (cyt. za: Becker, 2006, s. 176). Reagan, zaznacza Ron Becker (2006, s. 176-177), w ten sposób wyraził ideologię, która kształtuje myślenie Amerykanów o rodzinie i narodzie. Stanowisko ówczesnego prezy- 
denta nakłada na rodziny ogromną odpowiedzialność, materialną i ideologiczną, mają one bowiem zapewnić stabilność społeczną bez większej pomocy władz państwowych czy lokalnych społeczności. Wspiera to, podkreśla Becker, neoliberalny cynizm wobec państwa i publicznych rozwiązań problemów społecznych.

\section{Symbioza polityki z kulturą popularną}

Bauman, twierdzi Peter Beilharz (2000, s. 35-36), wskazuje na bogactwo interpretacji kategorii kultury, zwracając uwagę na trzy podstawowe nurty posługiwania się tym określeniem.

Pierwszy nurt uznaje kulturę za ideę hierarchiczną - jedni ludzi mają kulturę, drugim zaś jej brak. Kultura wiąże się zatem z własnością - nieważne, czy odziedziczoną, czy też nabytą - potrzebuje wsparcia, inaczej bowiem zostanie wyparta przez przyrodę i dzikość. Kulturę należy uprawiać. Ten sposób myślenia jest nasycony wartościowaniem (value-saturated). Według drugiego podejścia kultura jest koncepcją różnicującą, używaną, aby ustanowić różnice między ludźmi, czasami i miejscami. Przykładem może tu być Herodot, który - omawiając odległe krainy - pisał, że ich mieszkańcy są odmienni od nas. Można cenić wyżej naszą kulturę od ich kultury. Możliwy jest jednak trzeci, bardziej otwarty, system klasyfikacji, chaotyczny i nieprzypominający klasycznej, alfabetycznie ułożonej encyklopedii.

Pierwszy nurt jest narcystyczny czy też odnoszący się do samego siebie (self-referential), drugi zaś bardziej antropologiczny, a przynajmniej etnograficzny. W drugim różnica jest raczej zaobserwowana czy ustanawiana, a nie natychmiastowo wartościowana. Paradoksalnie drugie podejście może sugerować radykalną różnicę czy kulturalny relatywizm, przekonanie, że wszyscy ludzie robią to samo, choć inaczej. Trzeci nurt pojmowania kultury to właściwa całemu rodzajowi koncepcja kultury: rzeczywistość kultury jest tu postrzegana jako jedność. Bauman nawiązuje do pracy Clifforda Geertza, dla którego wszyscy ludzie funkcjonują w ramach tej samej ścieżki czy procesu życia. Przypomina to strukturalizm Claude’a Lévi-Straussa, dla którego wszelkie różnice są emitowane międzykulturowo, choć wywodzą się z uniwersalnych i jednorodnych własności mózgu. Kultury nie należy, według Baumana, wiązać ze strukturą, symbolem czy językiem, wszak nieład jest bardziej prawdopodobny niż wystąpienie struktury. Struktura to bardziej nadzieja niż rzeczywiste osiągnięcie. Działalność strukturyzacji konstytuuje ludzką praxis, ludzki sposób bycia w świecie. Praxis, czyli bycie-w-świecie (being-in-the-world), uzależnione jest od narzędzi i języka. Kultura jest nieustannym wysiłkiem wydostania się poza napięcie pomiędzy kreatywnością, wolnością a zależnością. 
Dla Baumana trzeci nurt jest najbardziej wartościowy, pozwalając wyjść poza podział na kulturę popularną - sugerujący jej niewinność i oddolność - i kulturę masową, postrzeganą nade wszystko jako narzędzie kontroli społecznej.

Wczesna anglojęzyczna praca Baumana, Kultura jako praxis (2012; oryg. wydana w roku 1973), opiera się na założeniu, że ludzka potrzeba stworzenia struktury i ładu odgrywa przemożny wpływ na indywidualną wolność, odpowiedzialność moralną i stosunki międzyludzkie. Jakkolwiek w późniejszym, globalizującym się świecie, jak zaznacza Robert Campain (2008, s. 193-194), władza zmienia swój kształt, lecz nadal dzieli ludzkość, odbierając jednostkom ich autonomię i odzierając je z godności. Podmiotami władzy są rządy i korporacje, jej zaś narzędziami - kapitał, technologia i władza. Władza daje uprzywilejowanej elicie szansę dokonywania wyborów, które wpływają na innych. Władza oznacza dla jednych możność zachowania autonomii, a dla innych - brak wolności. Wolność jednostki nie tylko nie jest uniwersalnym stanem ludzkości, ale w ogóle jest wytworem historycznym i społecznym; wolność jest w tej mierze władzą, w jakiej inni muszą się doń przystosować.

Dla Baumana, kontynuuje Campain (2008, s. 195-196), kwestia relacji władzy z kulturą nieodrodnie wiąże się z zagadnieniem ludzkiej wolności, nierówności i wykluczenia. Każde zaprowadzanie ładu, który ma chronić jednostki i całe społeczeństwa przed anarchią i chaosem, oznacza kreowanie podziału na nas i na nich. Najwyższą stawką w tej grze jest wykreowanie rzeczywistości, w której każdy będzie mógł wytwarzać i kształtować uwarunkowania, w jakich przebiega jego egzystencja. Można by rzec w duchu Lévi-Straussa, że władza wykrawa elementy naturalnego wszechświata i przekształca je w domenę kulturowej praxis. Istotne jest, że Bauman nie postrzega strukturyzacji jako osiągnięcia, lecz jako permanentną ludzką działalność, która koniec końców wytwarza nieład i wieloznaczność, których uniknięcie napędzało zmiany strukturalne. Ambiwalencja jest wrogiem ładu, gdyż podkopuje przekonanie o jego stabilności i jednoznaczności, skąd bierze się praktyka wykluczania i represjonowania tych, którym odmówiono miejsca w zaprowadzonym porządku.

Dla Baumana kluczowe pytanie, na które trzeba odpowiedzieć, brzmi: „Co powinniśmy zrobić i jak powinniśmy żyć?”. Kwestia władzy ma zatem fundamentalne znaczenie, a sposoby jej sprawowania - przez jednostki w ich codziennym współoddziaływaniu na siebie, także na szerszym społecznym i globalnym poziomie - znajdują się w centrum ludzkiej kondycji. Dla Baumana wyobraźnia socjologiczna musi dociekać tego, jak funkcjonuje władza, jakie ma konsekwencje dla wolności i odpowiedzialności moralnej (Campain, 2008, s. 193).

Jest rzeczą niewątpliwą, powtórzmy za cenionym przez Baumana historykiem Erikiem Hobsbawmem (2010, s. 180), że reakcją na obecną fazę globalizacji, głębokie i bezprecedensowo ultraszybkie przemiany społeczne, ekonomiczne 
i polityczne, są nastroje szowinistyczne (niekiedy rasistowskie), ksenofobiczne. Błędem byłoby jednak mówienie o powrocie do tradycji - nawet jeśli wiele ruchów jakąś jej zmistyfikowaną wersję promuje, przynajmniej werbalnie - te ruchy są bowiem na wskroś nowoczesne i antytradycyjne. Skrajnym tego świadectwem są grupy dżihadystów. Jak podkreśla Aijaz Ahmad (2008, s. 14), islamscy ekstremiści niewiele wiedzą o teologii swej religii. Można zatem powiedzieć, że nie są to we właściwym sensie tego słowa fundamentaliści. To innowatorzy, bliżsi raczej elitarnym grupom rewolucyjnych terrorystów w carskiej Rosji niż tradycji muzułmańskiej. Gwoli ścisłości, w płynnym, wieloznacznym świecie istnieją mniej dramatyczne przykłady. Eric Hobsbawm

[...] był świadkiem narodzin wśród młodego pokolenia w jednej z części Północnej Walii całkowicie nietradycyjnego - w rzeczy samej, zupełnie kontrtradycyjnego, zważywszy na jego zamiłowanie do pubów i alkoholu - walijskiego bojowego nacjonalizmu, podczas gdy kaplice opustoszały, pastorzy i uczeni amatorzy przestali być głosem społeczności, a wskutek spadku publicznego oddania dla abstynencji zniknął najbardziej oczywisty sposób okazywania przez jednostki przynależności do purytańskiej kultury i wspólnoty (Hobsbawm, 2010, s. 181).

Przypomnijmy w tym miejscu, że pojęcie kultury, patrząc semantycznie, początkowo oznaczało proces materialny, z czasem dopiero nabrało znaczenia metaforycznego, dotycząc spraw ducha. Jak zauważa Terry Eagleton (2012), łaciński źródłosłów kategorii kultury to słowo colere określające wiele rzeczy, „[...] od kultywacji, przez zamieszkiwanie, czczenie, aż po ochronę. W znaczeniu zamieszkiwania słowo to przeszło przemianę od łacińskiego colonus po współczesny kolonializm" (Eagleton, 2012, s. 8). Ten brytyjski autor unaocznia, że państwo ze swej natury powinno pozostawać instytucją nadrzędną, w której ramach podziały będą harmonizowane przez społeczeństwo obywatelskie - odbywa się to na drodze kulturowej (Eagleton, 2012, s. 14-15). Kultura w tym ujęciu, powtórzmy za teoretykiem kultury, to swoista pedagogika etyczna, wyzwalająca w społeczeństwie zbiorową jaźń, w myśl której jego członkowie stają się obywatelami politycznymi.

Trudno zatem odmówić racji Baumanowi, według którego ostatecznie tożsamość elementów kulturowych - ich jedność, całość, swoistość - „jest pokłosiem precyzyjnie wytyczonej i pilnie strzeżonej granicy" (Bauman, 2012, s. 48). Jej twórcy i strażnicy przekonują, że jest odwrotnie. Dodajmy, iż polski myśliciel konsekwentnie przeciwstawia się komunitaryzmowi, uznając go za projekt antynowoczesny, żądający sankcjonowania norm kulturowych poprzez instytucje publiczne:

Wspólnota kulturowa staje się obszarem kulturowego przymusu - tym boleśniejszego, że jest odczuwany, przeżywany jako przymus - ponieważ może przetrwać wy- 
łącznie kosztem ograniczenia swoim członkom wolności wyboru. Nie może trwać bez ścisłego nadzoru, dyscyplinującej musztry i surowych kar za wszelkiego rodzaju odstępstwa od norm (Bauman, 2012, s. 68, podkr. oryg.).

Przykładem takiego komunitariańskiego wykluczenia jest ideał Polaka katolika, zespalający czynniki o charakterze narodowym i religijnym (por. Czapnik, Omelan, 2015, s. 45-58).

Błędem byłoby twierdzenie, że wielość przybieranych tożsamości, ich różnorodność, a niekiedy napięcie - by nie rzec, jawna sprzeczność - między nimi, są czymś bezprecedensowym, wyróżnikiem czasów płynnej, lekkiej, późnej nowoczesności alias ponowoczesności. Patrząc historycznie, nowoczesność to epoka konkurencyjnych zabiegów rozmaitych grup politycznych, etnicznych/narodowych i wyznaniowych o kreowanie ludzkiej tożsamości.

Tożsamości, pisze metaforycznie Hobsbawm (2010, s. 132), nie wolno mylić z parą butów, która to ma do siebie, że w danym momencie można nosić tylko jedną. Ludzie zwykli mieć - a ściślej: mieli i nadal mają - jednocześnie kilka odmiennych obiektów przywiązania i lojalności. W tym samym czasie może ich trapić troska o różne wymiary życia, z których - w pewnych okolicznościach każdy może stać się tym głównym. Innymi słowy:

Przez długi czas owe różne rodzaje przywiązania nie nakładały na daną osobę przeciwstawnych wymogów, można więc było bez problemu czuć się synem Irlandczyka, mężem Niemki, członkiem społeczności górniczej, robotnikiem, kibicem FC Barnsley, liberałem, wyznawcą pierwotnego metodyzmu, angielskim patriotą, a nawet republikaninem i zwolennikiem imperium brytyjskiego (Hobsbawm, 2010, s. 132-133).

To stwierdzenie można dialektycznie zestawić z Baumanowską tezą, że w lekkiej nowoczesności jednostki są przeświadczone, że muszą bezustannie wybierać tożsamości, podczas gdy uprzednio były one zhierarchizowane i uporządkowane - w każdej szczególnej sytuacji wydawało się, że muszą wybrać wyłącznie jedną tożsamość (Nijhof, 1998, s. 90).

\section{Nowoczesna polityka w popkulturowym przebraniu}

Nie bez racji pisze S.N. Eisenstadt:

Nowoczesne reżimy konstytucyjno-demokratyczne wykrystalizowały się wraz z nowoczesnością. $Z$ tego względu podzielają one pewne napięcia i sprzeczności kulturowego programu nowoczesności, rozwinięte w epoce wielkich rewolucji i Oświece- 
nia (które, rzecz jasna, sięgają korzeniami wcześniejszych epok historii europejskiej) (Eisenstadt, 1996, s. 25).

Nowoczesność zwiastowała wiarę w możliwość aktywnego tworzenia - za pomocą ludzkiego działania - kluczowych elementów społecznych, kulturowych i przyrodniczych porządków. Innymi słowy można stwierdzić, że mieliśmy do czynienia z połączeniem racjonalności instrumentalnej (Zweckrationalität) i racjonalności opartej na wartościach (Wertrationalität), czego ucieleśnieniem stała się sama nauka. Tym, co różni nowoczesną politykę od jej przednowoczesnych form, jest fakt, że jej uprawnionym składnikiem jest protest. Jest to ściśle związane z projektem wyzwolenia człowieka, próbującego połączyć w harmonijną całość „wolność i równość, sprawiedliwość i autonomię, solidarność i tożsamość". Owo legitymizowane dążenie do emancypacji stało się narzędziem nacisków peryferii na centrum (por. Eisenstadt, 1996, s. 27, 30).

Pośród kluczowych napięć kulturowego programu nowoczesności można wymienić napięcia między: wolnością a równością, naciskiem na dobry ład społeczny a zainteresowaniem szczególnymi interesami określonych części społeczeństwa, koncepcją autonomicznej jednostki a wspólnotą, samodzielnym społeczeństwem obywatelskim a państwem, a także - last but not least - między utopijnym a racjonalnym, proceduralnym wymiarem tego programu. $\mathrm{W}$ zasadzie powyższe podziały można nałożyć na konstrukcję nowoczesnej polityki - z jednej strony rewolucyjnej, z drugiej zaś zwyczajnej, powszedniej. Napięcia między rutynową i rewolucyjną polityką są zwiększane poprzez dwa kolejne elementy procesu politycznego w społeczeństwach nowoczesnych. Pierwszym z nich jest tendencja do czynienia politycznymi wielu społecznych problemów i konfliktów, a drugim - nieustanne redefiniowanie tego, czym jest polityczne (political). Specyfiką nowoczesnych reżimów politycznych jest czynienie politycznymi szeregu kwestii, które w poprzednich reżimach takimi nie były, pozostawiano je sferze prywatnej, tradycji (Eisenstadt, 1996, s. 31-34).

Bauman, piszą Ian Varcoe i Richard Kilminster (1996, s. 217), zainteresowany jest w godzeniu dwóch stron prawdy głoszonej przez Marksa, który - według polskiego socjologa - zajmował się kluczowym problemem: dowodził że ludzkie życie nigdy nie jest w pełni wolne, lecz od samego początku owa wolność jest ograniczana. Ludzkie działanie jest swobodne (w znaczeniu woli czy motywacji). Wieloletnie zainteresowanie Baumana kulturą wywodzi się z rozpoznania przedstawionego faktu i wiąże kulturę z ludzką egzystencją. Kultura jest ściśle powiązana $\mathrm{z}$ władzą, zdolna jest bowiem do strukturyzowania świata w większej mierze niż inne zjawiska. Oczywiście wszelki ład kreuje nowe problemy i ambiwalencję. Ludzkie życie jest aktywne, będąc - w kategoriach Marksowskich jednocześnie praxis. Innymi słowy kultura jest strukturą. Niemniej jednak jest 
ona również praxis. Na poziomie politycznym i etycznym celem Baumana jest poszerzenie sfery ludzkiego działania.

Varcoe i Kilminster (1996, s. 218) piszą, że Bauman atakuje dualistyczną ideę, że kultura wiąże się z wartościami pojmowanymi jako coś odrębnego od struktury. Rzecz nie sprowadza się bynajmniej do tego, czy wszyscy wspierają, czy podzielają centralny system wartości, ani tego, czy struktury zmuszają ludzi do podporządkowania. Poza tym koncepcja problemów, jakie stają przed socjalizmem rozumianym jako horyzont oczekiwań i żądań, zależy od idei Gramsciego, zwracającego uwagę, że istniejący ład konstytuuje tak zwany zdrowy rozsądek. Status quo jest pewną istniejącą kulturową rzeczywistością, wszelka zaś przyszła alternatywa będzie musiała przyoblec się w podobną kulturową formę. Oba argumenty ściśle wiążą się z postrzeganiem kultury jako praxis - wspólnotowego, ludzkiego sposobu konstruowania rzeczywistości. Kultura nie jest bynajmniej czymś dodanym do stosunków społecznych, pojmowanych jako coś cięższego, trudniejszego i bardziej fundamentalnego. Kultura ma janusowe oblicze: jest jednocześnie obiektywną podstawą subiektywnie istotnego doświadczenia, i subiektywnym przyswojeniem pozaludzkiego, obcego świata. W Kulturze jako praxis Bauman (2012) sugeruje, że ładotwórcza funkcja kultury jest ściśle powiązana ze znaczeniem państwa w czasach nowoczesnych. Potem Bauman odwołuje się do metafory Ernesta Gellnera - ogrodu przeciwstawionego dzikiej kulturze. W nowoczesnych społeczeństwach wieloznaczność staje się problemem, jej wyeliminowanie staje się ważną misją.

Gwoli ścisłości, w pewnych sytuacjach, na przykład takich, których ucieleśnieniem była Zagłada, niechęć do wieloznaczności oznaczała tendencję do fizycznego wyeliminowania jej nośników. W przednowoczesnej Europie

Żydzi byli osobliwością, istotami, które naruszały racjonalny porządek i moralną harmonię wszechświata. Nie zaliczali się ani do nienawróconych pogan, ani do heretyków odszczepieńców, a więc dwóch kategorii, które wyznaczały gorliwie strzeżone i możliwe do obrony chrześcijańskiego świata. Żydzi siedzieli, by tak rzec, okrakiem na barykadzie, naruszając tym samym jej nienaruszalność (Bauman, 2013, s. 92-93).

Ludobójstwo Żydów miało służyć biologicznemu przemodelowaniu ludzkości, które było celem samo w sobie, a nie środkiem do innego celu (Traverso, 2011, s. 9). Celem krytycznej teorii polityki powinno być ujawnianie wszelkich mechanizmów dehumanizacji, jakie mogłyby prowadzić do zbrodni.

Z perspektywy rządzących nader korzystne jest kulturowe ukazywanie istniejącego ładu jako nie produkty walk społecznych, lecz czegoś naturalnego. Nowoczesne państwa narodowe nie mogłyby istnieć bez masowej edukacji i tak zwanej kultury narodowej. Nie jest przypadkiem, że ministerstwo, które w epo- 
ce de nomine internacjonalistycznej Polski nazywało się po prostu Ministerstwem Kultury, obecnie jest Ministerstwem Kultury i Dziedzictwa Narodowego. Poza sporem pozostaje, że „dziedzictwo narodowe” jest częścią kultury, lecz - w mniemaniu rządzących - elementem najbardziej wartościowym, godnym szczególnej troski i pielęgnacji. Skłania to do refleksji, że kapitalistyczna Polska przeszła proces dyskursywnej renacjonalizacji.

Sposób ujmowania przez Baumana władzy jest powiązany z centralną rolą, jaką przypisuje on kulturze, przy czym to zjawisko interpretuje szerzej, niż zwykło się to czynić w tradycjach brytyjskiej i amerykańskiej. Esencją jest strukturyzacja, ludzka zdolność do tworzenia ładu, oddzielania, rozgraniczania. Władza jest sposobem, w jaki owa strukturyzacja zachodzi pomiędzy grupami ludzi. Władza jest zatem równie endemicznym wymiarem ludzkiej kondycji jak kultura. Władza działa poprzez przewidywanie zachowania pewnych grup, odmiennego od zachowania innych grup. Prawdą może być też coś odwrotnego pewne grupy mogą uczynić siebie nieprzewidywalnymi dla innych, co daje im więcej władzy. Można uznać, ze stopień kontroli grupy lub jednostki w danej sytuacji zależy od tego, w jakiej mierze może ona determinować zachowanie innych. Takie rozszerzenie kontroli oznacza eliminowanie niepewności z zachowania innych, ograniczanie pola jej manewru. Kontrola rośnie w sytuacji, gdy zachowanie drugiej strony staje się coraz mniej nieprzewidywalne, a zatem jest powtarzalne, rutynowe i kierujące się zasadami. Można to uczynić na różne sposoby. Jeżeli stosujemy przymus, potencjalna kara ma odstraszać od zbaczania z wyznaczonej drogi. Można postąpić inaczej - pozbawić jednostkę lub grupę możliwości dostrzeżenia, że dany stan rzeczy jest dziełem ludzkim, a zatem można go zmienić. Skuteczne uniemożliwienie podmiotowi dokonywania wyboru kierunku działania czyni go nieistotnym aktorem, z którym nie trzeba się liczyć (Varcoe, Kilminster, 1996, s. 218-219).

Jasna jest przewidywalność i ograniczenie pola manewru podmiotu, aż do zredukowania go do roli przedmiotu zabiegów innego podmiotu. Symbolem tego może być panoptyczna władza kadry zarządzającej w fabryce (Varcoe, Kilminster, 1996, s. 220). Fordowska fabryka była symbolem trwałej, solidnej nowoczesności, ładu wczesnego państwa narodowego. Niemniej jednak, pomimo, wydawałoby się, jednoznacznej przewagi kierujących nad szeregowymi pracownikami, trudno przyjąć, że wszystko stracone, nie sposób bowiem w sposób uzasadniony zaakceptować takiego stanowiska (Bauman, Lyon, 2013, s. 200-201). Kłopot polegał na tym, jak powiedziała swemu szefowi odważna pracownica fabryki General Electric (GE) w Bridgeport, że ludzie nie są automatami - mają oczy, aby widzieć, uszy, aby słyszeć, i usta, aby mówić (Noble, 2011, s. 37). Menedżerowie GE wdrożyli badania czasu i pracy, lecz robotnicy rozwinęli szeroki repertuar technik sabotowania poleceń przełożonych, ignorowania ich oczekiwań, jeśli były one sprzecz- 
ne $\mathrm{z}$ ich interesami. To walka decydowała o tym, kto będzie miał ostateczny głos w sprawie tego, kto, co i kiedy będzie robić (Noble, 2011, s. 37).

Ciekawy jest przykład kapitalizmu per se:

Stabilność kapitalizmu uzyskała kulturowy fundament w postaci ideału dobrego życia, uznanych powszechnie celów działania, legitymizacji pragnień jako wyrazów potrzeb, schematów poznawczych decydujących o sposobie postrzegania świata, a nade wszystko sposobu, w jaki przeciągnięto linię graniczną pomiędzy tym, co „realistyczne”, a tym, co „utopijne”. Ten fundament kulturowy pozwala reprodukować całość kapitalistycznych stosunków przy niewielkiej tylko ingerencji ze strony aparatu przemocy albo i całkiem bez potrzeby do niej się uciekania (Bauman, 2010, s. 115).

Program reality TV Superniania pokazuje, jak można skłaniać populację do posłuszeństwa, przybierając formę rozrywkowego produktu przemysłu kulturalnego.

\section{Superniania: neoliberalna strażniczka porządku}

Płynne życie, a zatem życie jednostki w epoce płynnej nowoczesności, jest bez reszty oddane konsumpcji (Bauman, 2007, s. 17). Traktuje ona świat, jego wszelkie elementy (ożywione i nieożywione) jako przedmioty do spożycia, które tracą swój blask i wartość - innymi słowy użyteczność - w miarę używania. Najgorsze, co może spotkać każdego, to bycie wybrakowanym konsumentem, innymi słowy człowiekiem, którego życie jest przeznaczone na przemiał (Bauman, 2004). Stąd zapewne rodzi się nowy indywidualizm, zanikanie ludzkich więzi i solidarności (Bauman, 2006, s. 255). Jak zauważa Tim May w przedmowie do jednej z książek Baumana, niegdyś próbowano rozwiązywać problemy społeczne w ramach tworzonych przez ludzi wspólnot, w obecnej zaś fazie kapitalizmu walczy się nie tyle z ubóstwem, ile z ubogimi, do czego wykorzystuje się system karny, utrwalający przepaść między ludźmi a ich środowiskiem (May, 2006, s. 14). Gwoli ścisłości, jak zauważa cytowany przez Baumana (2000, s. 94) Jeremy Seabrook, biedy nie można wyleczyć, nie jest ona bowiem symptomem choroby kapitalizmu. Jest dokładnie odwrotnie: stanowi świadectwo jego doskonałego zdrowia, bodziec do większej akumulacji i wzmożonych wysiłków, które skądinąd dotykają również najbogatszych i najbardziej uprzywilejowanych.

W zakończeniu książki wywiadu Bauman zauważa, że obowiązkiem socjologa - choć ma raczej na myśli w ogóle badacza człowieka i społeczeństwa - jest oglądanie telewizji (Bauman, 2014, s. 163-164). Ludzie spędzają znaczną część życia na oglądaniu telewizji i zdobywają poprzez nią dużą część swojej wiedzy o świecie. Współczesny Lebenswelt, główny przedmiot badań społecznych, bez 
telewizyjnych składników byłby niekompletny. Nie powinno się odwracać plecami do znacznej części ludzkiego doświadczenia, toteż uczeni humaniści, wybierając programy do oglądania, nie powinni się kierować własnymi gustami, lecz preferencjami estetycznymi i rozrywkowymi ogółu. Nie należy lekceważyć telewizji, nawet w jej najbardziej - pozornie - błahych przejawach, może ona bowiem wywołać panikę moralną, podsycając społeczne niepokoje (Bauman, 2016, s. 7).

Wziąwszy pod uwagę krytycyzm Baumana wobec obecnej neoliberalnej fazy kapitalizmu, wydaje się, że zgodziłby się on z Nickiem Couldrym (2008, s. 3), że neoliberalizm to reżim okrucieństwa. Według Couldry’ego, to jedyny właściwy sposób określenia systemu, który organizuje zasoby społeczne i ludzką siłę roboczą, aby wymagać od uczestników ciągłej lojalności, podporządkowania inwigilacji i zewnętrznemu kierowaniu, nawet w sferze najbardziej prywatnych spraw. „Prawdy” neoliberalizmu, twierdzi Couldry (2008, s. 3), byłyby - gdyby je wyłożyć otwarcie - nieakceptowalne, muszą zatem być przetłumaczone na rytuały odgrywania akceptowanych wersji wartości, od których owe okrucieństwo zależy. Wśród rytuałów neoliberalizmu istotną rolę odgrywa tak zwane reality $T V$, pod wieloma względami ucieleśnienie konsumpcjonizmu, jednej z kluczowych cech neoliberalnej fazy kapitalizmu.

Rację ma John Hartley (1992, s. 22), że teksty telewizyjne są polisemiczne, brak gwarancji, że jakieś szczególne znaczenie jest uprzywilejowane jako prawda. Najlepsze, co może uczynić badacz, to wskazać, jak teksty ograniczają własne znaczenie ideologicznymi „preferowanymi odczytywaniami”. W tej części analizie poddane zostanie przesłanie ideologiczne, jakie wyłania się z polskiej edycji trzech sezonów Superniani.

Ideologia neoliberalna podkreśla swój rzekomo wolnościowy charakter, wychodząc od specyficznej wizji człowieka, która jest na wskroś indywidualistyczna, a w neutralnym, analitycznym sensie tego słowa aspołeczna. Bauman (2010, s. 143) wyjaśnia to, odwołując się do dwóch pokrewnych sloganów - pierwszego, autorstwa Margaret Thatcher, drugiego - Petera Druckera, wybitnego specjalisty od zarządzania. Brytyjska premier stwierdziła, że „nie ma czegoś takiego jak społeczeństwo" (no such thing as society), istnieją tylko jednostki, mężczyźni i kobiety, i ich rodziny. Drucker przestrzega: „Nie oczekujmy już zbawienia od społeczeństwa”. Każdy odcinek nadawanego w stacji TVN reality show pokazywał prawdziwość powyższych konstatacji. Odwoływał się do wizji nuklearnej rodziny par excellence: nie było w niej miejsca dla rozszerzonej rodziny, szkoły, instytucji pedagogicznych, a nawet kolegów i koleżanek dzieci.

W jakimś sensie polska edycja Superniani była utopią klasy średniej, abstrahując rzecz jasna od daleko idącej nieostrości tej kategorii (Tittenbrun, 2016). Klasą średnią $\mathrm{w}$ tym sensie byli ludzie, którzy nie zmagali się z biedą i wykluczeniem, a jednocześnie nie należeli do bogatych elit. W polskich realiach był to jaskrawy te- 
atr okrucieństwa - ubóstwo, a niekiedy i nędza, wśród polskich dzieci są (pomimo wdrożenia programu socjalnego popularnie zwanego „500+”) poważnym problemem, a były nim jeszcze bardziej w połowie ubiegłej dekady, kiedy produkowano Supernianię (Tarkowska, 2005); według raportu UNICEF (2007) wśród państw rozwiniętych polskie dzieci znajdowały się w najgorszej materialnie sytuacji. Do dzieci, które doznają upokorzenia z powodu niedostatków materialnych, jeżdżąca luksusowym samochodem i posługująca się drogim laptopem marki Apple superniania Dorota Zawadzka (ówcześnie akademicka wykładowczyni psychologii na renomowanej prywatnej uczelni) nie zwykła przyjeżdżać. Nie powinno to zapewne dziwić. Problemu ubóstwa nie da się rozwiązać za pomocą - skądinąd dość wątpliwych zarówno psychologicznie, jak i etycznie - trików.

Innymi słowy bieda znów - niczym w epoce wiktoriańskiej - jest cierpieniem samozawinionym, a klasowe podziały i nieodrodne im upokorzenia uznaje się jako naturalne, a zatem niezmienne, toteż należy się z nimi pogodzić i je zaakceptować (Bauman, Tester, 2003, s. 88).

Dodajmy, że format Superniani legitymizował posługiwanie się inwigilacją, nadając jej pozór dobrotliwości, koniecznego składnika życia społecznego. W każdym odcinku ekipa TVN montowała kamery w domu danej rodziny - następnie emitowano krótkie materiały wideo ukazujące niegrzeczne dzieci i nieradzących sobie z wychowywaniem potomków rodziców. Zawadzka dzięki owej daleko idącej - jakkolwiek dobrowolnej - inwigilacji może rozpocząć swoją aktywność, wdrażając program naprawczy, swoisty odpowiednik programów dostosowania strukturalnego, jakie przez lata stosowały Bank Światowy i Międzynarodowy Fundusz Walutowy. Inwigilacja w Superniani to przykład korporacyjnej inwigilacji, która jest nieodrodnym składnikiem płynnej nowoczesności (Bauman, Lyon, 2013; Czapnik, 2016). Inwigilacja jawi się jako konieczny element współczesnego społeczeństwa, narzędzie umożliwiające kontrolę podporządkowanych jednostek i grup ze strony panujących.

Najbardziej znanym z trików superniani jest technika „karnego jeża” - poduszki, na której dziecko ma siedzieć za karę. Co ciekawe, w jednym z odcinków w serii drugiej obudzono dziecko, które zasnęło na tej poduszce - to nader zastanawiające $\mathrm{w}$ świetle faktu, że pozbawianie snu jest techniką zabronioną przez międzynarodowe konwencje: nie wolno jej stosować wobec więźniów i wrogów w trakcie wojny. Patrząc logicznie, skoro w sposób nieludzki traktuje się własne dziecko, to trudno oczekiwać bardziej ludzkiego traktowania przez inne osoby.

Jeżeli uznać, że stawką neoliberalizmu jest władza - władza pieniądza, władza polityczna, władza ideologiczna - to Superniania jawi się jako program na wskroś neoliberalny. Owo reality show, jeśli przyjrzeć się używanej retoryce - zwłaszcza w komentarzach lektora - to opowieść o walce o władzę. W tej narracji na mocy definicji podporządkowani - dzieci (można się zastanawiać, czy aby nie jest to 
metaforyczna figura robotników) - przejęli władzę nad tymi, którym owa władza $\mathrm{z}$ natury się należy, czyli rodzicami (figura klas dominujących?). Zawadzka przywraca zatem jedyny prawowity porządek - podporządkowanie dzieci rodzicom. Przytoczmy w tym miejscu parę cytatów, komentarzy lektora: „W dzisiejszym odcinku superniania odwiedzi rodzinę Szczepańskich, w której panem i władcą jest trzyletni Ksawery” (seria 1, odcinek 1); „Tu władzę absolutną sprawują Bartek i Kacper. Mali tyrani nie oszczędzają nikogo” (seria 1, odcinek 5); „Czy superniania położy kres tyranii bliźniaków?”, „W tym domu życie to ciągła walka” (seria 2, odcinek 11). Powyższe słowa jednoznacznie pokazują, że owa władza dzieci (robotników?) jest nieprawowita, tyrańska, toteż oczywiste jest, że interwencja zewnętrzna musi położyć jej kres, przywracając naturalny porządek.

Nie bez racji zauważa Bauman:

A że na ponad dwóch miliardach włączonych telewizorów słońce w ogóle nie zachodzi, świat widziany postrzegamy tak jak w telewizji. Pytanie, czy w telewizji widzimy prawdę, czy kłamstwo, nie ma sensu. Podobnie jak to, czy za jej sprawą świat jest lepszy, czy gorszy. No bo co byłoby punktem odniesienia dla takiej oceny? (cyt. za: Halawa, Wróbel, 2008, s. 188).

Podsumowując ten rozdział, można stwierdzić, że Superniania to ucieleśnienie kultury konsumpcyjnej. Największą nieprawością owej kultury jest obietnica, że panaceum na wszelkie ludzkie bolączki leży gotowe i trzeba je jedynie odnaleźć (zob. Bauman, Tester, 2003, s. 145-147). Rodzi to zgubne skutki. Pierwszym jest społeczne nieuctwo - zniechęcanie do szukania wspólnych dróg wyjścia z kłopotów, które wszakże mają często charakter systemowy, nie zaś ściśle biograficzny. Drugi to przyjmowanie wniosku, że życiowe problemy najlepiej rozwiązywać w pojedynkę. Trzeci zaś, że usuwa się wyłącznie objawy, a nie leczy choroby w postaci społecznych korzeni naszych problemów.

W ujęciu teoriopolitycznym kluczowe znaczenie ma, że konsumpcjonizm jest zjawiskiem rozszerzającym swoją logikę na wszelkie sfery życia, włącznie z polityką. Pozwala to krytycznie spojrzeć na popularność badań z zakresu marketingu politycznego, traktowania polityki i partii politycznych jako produktów, które należy sprzedać na rynku politycznym (najczęściej: wyborczym).

\section{Podsumowanie}

W zakończeniu warto przytoczyć - za Ollmanem (2003, s. 12) - opinię Mikołaja Kopernika o astronomach jego czasów: „byli oni niczym artysta, który gromadzi ręce, stopy, głowę i inne elementy z różnych modeli, każdego doskonale 
narysowanego, nietworzącego jednak pojedynczego ciała - nie stworzy ów artysta człowieka, lecz raczej potwora”. W tym kontekście trafna wydaje się krytyka podziału wiedzy na wzajemnie sobie obojętne i często wrogie dyscypliny akademickie, z których każda zajmuje się własną problematyką przy użyciu swoistych metod: harmonijne oświecenie, które nam obiecano, przekształciło się w kakofonię dźwięków. Co więcej, przecięto bardzo stare więzy pomiędzy wiedzą i działaniem, toteż uczeni unikają jakiejkolwiek odpowiedzialności wobec społeczeństwa, podczas gdy są jednocześnie dumni, iż wiedzą coraz więcej i więcej o coraz mniejszej i mniejszej cząstce świata (Ollman, 2003, s. 12). Trzeba uwypuklić, że Bauman - zwłaszcza w ostatnim ćwierćwieczu swej aktywności intelektualnej - uczynił wiele, aby wykazać, że można sprzeciwić się powyższemu trendowi, wykazując się przy tym poetycką wyobraźnią (Jacobsen, Marshman, 2008, s. 798-818).

Jakkolwiek Bauman konsekwentnie przez dziesięciolecia określał siebie mianem socjologa, istnieją poważne przesłanki, by nazwać go raczej myślicielem, a może nawet i mędrcem. Jeżeli powyższa analiza jest choć częściowo trafna, to nie jest zbyt ryzykowne twierdzenie, że Baumanowska dialektyka może być interesującą i płodną poznawczo inspiracją w badaniach teoriopolitycznych. Wydaje się, że może być ona antidotum na - krytykowane przez Klementewicza (2016) próby teoretyzowania polityki bez klas społecznych czy korporacji, i zbytnie skupianie się na kategorii polityczności.

Aktualność zachowuje poczyniona przez Baumana dekadę temu konstatacja:

Nowoczesność przyniosła wolność wraz ze środkami znieczulającymi zarówno na jej bóle, jak i na jej wyzwanie: wraz z patentowanymi sposobami na krycie się przed jednym i drugim (wspomnijmy choćby cedowanie odpowiedzialności za wybór na instancje biurokratyczne). Pod oszałamiająco trudnym problemem wyboru postawiono znacznie prostszą wskazówkę konformizmu wobec normy postępowania w zgodzie z przepisami, a kwestię niewyrażalnego „ostatecznego" rozwiązania owego problemu utożsamiano $\mathrm{z}$ całkiem praktycznym z pozoru zadaniem precyzacji i ujednoznacznienia norm (Bauman, Kubicki, Zeidler-Janiszewska, 2009, s. 64-65).

\section{Literatura}

Ahmad, A. (2008). „Islam, Islamisms and the West”. W: L. Panitch, C. Leys (red.). Socialist Register, vol. 44: Global Flashpoints: Reactions to Imperialism and Neoliberalism. London: The Merlin Press.

Bauman, Z. (2000). Globalizacja. I co z tego dla ludzi wynika, przeł. E. Klekot. Warszawa: Państwowy Instytut Wydawniczy. 
Bauman, Z. (2004). Życie na przemiał, przeł. T. Kunz. Kraków: Wydawnictwo Literackie. Bauman, Z. (2006). Płynny lęk, przeł. J. Margański. Kraków: Wydawnictwo Literackie.

Bauman, Z. (2007). Płynne życie, przeł. T. Kunz. Kraków: Wydawnictwo Literackie.

Bauman, Z. (2010). Socjalizm. Utopia w działaniu, przeł. M. Bogdan. Warszawa: Wydawnictwo Krytyki Politycznej.

Bauman, Z. (2012). Kultura jako praxis, przeł. J. Konieczny. Warszawa: Wydawnictwo Naukowe PWN.

Bauman, Z. (2013). Nowoczesność i Zagłada, przeł. T. Kunz. Kraków: Wydawnictwo Literackie.

Bauman, Z. (2014). Rozmowy o socjologii. Zygmunt Bauman w rozmowie $z$ Michaelem-Hviidem Jacobsenem i Keithem Testerem, przeł. P. Tomanek. Warszawa: Wydawnictwo Naukowe PWN.

Bauman, Z. (2016). Obcy u naszych drzwi, przeł. W. Mincer. Warszawa: Wydawnictwo Naukowe PWN.

Bauman, Z., Kubicki, R., Zeidler-Janiszewska, A. (2009). Życie w kontekstach. Rozmowy o tym, co za nami, i o tym, co przed nami. Warszawa: Wydawnictwa Akademickie i Profesjonalne.

Bauman, Z., Lyon, D. (2013). Płynna inwigilacja. Rozmowy, przeł. T. Kunz. Kraków: Wydawnictwo Literackie.

Bauman, Z., Tester, K. (2003). O pożytkach z wątpliwości. Rozmowy z Zygmuntem Baumanem, przeł. E. Krasińska. Warszawa: Sic!

Becker, R. (2006). „ «Help Is on the Way!»": Supernanny, Nanny 911, and the Neoliberal Politics of the Family". W: D. Heller (red.). The Great American Makeover: Television, History, Nation. New York-Basingstoke: Palgrave Macmillan.

Beilharz, P. (2000). Zygmunt Bauman - Dialectic of Modernity. London-Thousand Oaks-New Delhi: Sage Publications.

Campain, R. (2008). „Bauman on Power: From 'Solid' to 'Light'?” W: M.H. Jacobsen, P. Poder (eds.). The Sociology of Zygmunt Bauman: Challenges and Critique. Aldershot-Burlington, VT: Ashgate.

Couldry, N. (2008). „Reality TV, or the Secret Theater of Neoliberalism”. Review of Education, Pedagogy, and Cultural Studies, vol. 30, no. 3.

Czapnik, S. (2016). „Liquid Surveillance”. W: T. Blackshaw (ed.). The New Bauman Reader. Manchester: Manchester University Press.

Czapnik, S., Omelan, G. (2015). „Jak Polak, to katolik. Odcienie nacjonalizmu Kościoła rzymskokatolickiego w Polsce”. W: A. Kusztal, S. Czapnik (red.). Religia i Kościoły w polskiej przestrzeni publicznej. Opole: Wydawnictwo Uniwersytetu Opolskiego.

Eagleton, T. (2012). Po co nam kultura?, przeł. A. Górny. Warszawa: Muza.

Eisenstadt, S.N. (1996). „The Cultural Programme of Modernity and Democracy: Some Tensions and Problems". W: R. Kilminster, I. Varcoe (eds.). Culture, Modernity and Revolution: Essays in Honour of Zygmunt Bauman. London-New York: Routledge. 
Halawa, M., Wróbel, P. (koncepcja i wyb.) (2008). Bauman o popkulturze. Wypisy. Warszawa: Wydawnictwa Akademickie i Profesjonalne.

Hartley, J. (1992). Teleology: Studies in Television. London-New York: Routledge.

Hobsbawm, E. (2010). Narody i nacjonalizm po 1780 roku, przeł. J. Maciejczyk, M. Starnawski. Warszawa: Wydawnictwo Difin.

Jacobsen, M.H., Marshman, S. (2008). „Bauman's Metaphors: The Poetic Imagination in Sociology”. Current Sociology, vol. 56, no. 5.

Klementewicz, T. (2016). „Politics Without Classes and Corporations, Political Science Without Political Economy: The Science of the Political or Politics". Studia Krytyczne / Critical Studies, 2.

May, T. (2006). „Przedmowa wydawcy”, przeł. S. Obirek. W: Z. Bauman. Praca, konsumpcjonizm i nowi ubodzy. Kraków: Wydawnictwo WAM.

Nijhof, P. (1998). „The Right to Inconsistency”. Theory, Culture \& Society, vol. 15, no. 1.

Noble, D.F. (2011). Forces of Production: A Social History of Industrial Automation. New Brunswick-London: Transaction Publishers.

Ollman, B. (2003). Dance of the Dialectic: Steps in Marx's Method. Urbana-Chicago, IL: University of Illinois Press.

Such, J. (1992). Dialektyczne wizje świata. Warszawa-Poznań: Wydawnictwo Naukowe PWN.

Tarkowska, E. (2005). „Child Poverty in Poland”. Polish Sociological Review, 151.

Tittenbrun, J. (2016). „Klasa średnia - mit czy byt?”. Studia Krytyczne / Critical Studies, nr 2.

Traverso, E. (2011). Europejskie korzenie przemocy nazistowskiej, przeł. A. Czarnacka. Warszawa: Książka i Prasa.

UNICEF (2007). Child Poverty in Perspective: An Overview of Child Well-being in Rich Countries. UNICEF: Innocenti Research Center.

Varcoe, I., Kilminster, R. (1996). „Appendum: Culture and Power in the Writings of Zygmunt Bauman”. W: R. Kilminster, I. Varcoe (eds.). Culture, Modernity and Revolution: Essays in Honour of Zygmunt Bauman. London-New York: Routledge.

\section{Streszczenie}

Celem artykułu jest wskazanie na płodność poznawczą dialektycznego myślenia w badaniach teoriopolitycznych - na przykładzie późnej twórczości Zygmunta Baumana. Tekst składa się z trzech rozdziałów. Najpierw omówiono Baumanowską dialektykę kultury i polityki. Następnie uwypuklono politykę jako projekt kulturowy. W trzecim rozdziale przeanalizowano polską edycję reality show Superniania. W podsumowaniu zwrócono uwagę na doniosłość teoriopolityczną Baumanowskiej dialektyki.

Słowa kluczowe: dialektyka, Zygmunt Bauman, płynna nowoczesność, telewizja 